\title{
Familial cutaneous collagenoma
}

INSERM

\section{Source}

INSERM. (1999). Orphanet: an online rare disease and orphan drug data base. Familial cutaneous collagenoma. ORPHA:53296

Familial cutaneous collagenoma is a connective tissue nevus characterized by multiple, flesh-colored asymptomatic nodules distributed symmetrically on the trunk and upper arms (mainly on the upper two-thirds of the back), manifesting around adolescence. The skin biopsy reveals an accumulation of collagen fibers with reduction in the number of elastic fibers. Cardiac anomalies may be observed. Familial cutaneous collagenoma follows an autosomal dominant mode of transmission. 